\title{
The Origins of Spectra, an Organization for LGBT Mathematicians
}

\section{Robert Bryant, Ron Buckmire, Lily Khadjavi, and Douglas Lind}

On November 3, 1992, the citizens of Colorado passed an amendment to the state constitution that invalidated local ordinances in Denver, Boulder, and Aspen banning discrimination on the basis of sexual orientation. More importantly, it prohibited the passage of any further laws of this sort at the state or local level. When Colorado's Amendment 2 passed, the Joint Mathematics Meetings (JMM) were scheduled to be held in Denver in January 1995. Two mathematicians, acting independently, felt strongly that this meeting should be moved and wrote individual letters to the leadership of the American Mathematical Society (AMS) and the Mathematical Association of America (MAA) urging them to take this unprecedented action.

This article tells the story of what happened after Colorado's Amendment 2 passed and how our professional societies responded. The national consequences were profound, leading to a landmark decision in 1996 by the United States Supreme Court. Despite the prospect of serious financial consequences and possible opposition by members, the brave decision to move the 1995 JMM from Denver ${ }^{1}$ to San

Robert Bryant is the Phillip Griffiths Professor of Mathematics at Duke University. His email address is bryant@math. duke.edu.

Ron Buckmire is professor of mathematics, associate dean for curricular affairs, and director of the Core Program at Occidental College in Los Angeles, CA. His email address is ron@oxy. edu.

Lily Khadjavi is an associate professor in the Department of Mathematics at Loyola Marymount University. Her email address is $1 \mathrm{khadjavi@1mu.} \mathrm{edu.}$

Douglas Lind is professor emeritus in the Department of Mathematics of the University of Washington, Seattle. His email address is 7ind@math .washington. edu.

${ }^{1}$ As we explain later, the climate for LGBT people in Colorado is now very different from what it was in the 1990 s.

For permission to reprint this article, please contact: reprint-permission @ams.org.

DOI: https://dx.doi.org/10.1090/noti 1890
Francisco affirmed to lesbian, gay, bisexual, and transgender $\left(\right.$ LGBT $\left.^{2}\right)$ mathematicians that they mattered.

An informal get-together at that meeting led to annual events, and ultimately to the creation of Spectra, an organization for LGBT mathematicians and their allies. It is a story worth knowing, even a quarter-century later.

\section{Prologue and Colorado's Amendment 2}

Today it may be difficult for some to imagine the plight of sexual minorities in the 1970s and 1980s. LGBT people faced the reality of being fired, denied housing, forcibly outed, abandoned by their families, or even imprisoned should their sexual orientation become known-or suspected-by others [16].

Many adopted secrecy and self-censorship to cope, often with very destructive outcomes. One measure of the level of anti-LGBT stigma in our society at the time is that for years the law treated gay men and lesbians as criminals, although this was only selectively enforced. In 1986 the United States Supreme Court ruled in Bowers v. Hardwick that Georgia's anti-sodomy statute was constitutional [3]. Georgia's law criminalized sexual behavior between consenting adults of the same sex in the privacy of their home, with penalties of up to twenty years in jail.

Overlaying this damning judicial decision was the enormous tragedy of AIDS, a time when finding a small sore or spot on one's skin could well mean a relentless descent to a painful death from a disease with no effective treatment [29]. In 1992, the year that Colorado's Amendment

\footnotetext{
${ }^{2}$ We have adopted the acronym LGBT throughout this article to reflect the terminology and labels that were often chosen in the 1990s to describe the people who were targeted and impacted by Amendment 2. Today, more inclusive terms can be used to describe the full spectrum of members of this community.
} 


\section{HISTORY}

2 passed, 23,411 people in the United States died from AIDS [31].

In response to the oppression faced by many LGBT people at the time, gay rights groups in the US started advocating for legal protections from the sort of blatant discrimination many had experienced [13]. In Colorado, the cities of Denver, Boulder, and Aspen all passed ordinances in the early 1980s protecting gays and lesbians from discrimination in housing, employment, and public accommodations.

A number of groups opposed to civil rights for LGBT people were either begun in or moved to Colorado. These included the Family Research Institute, Christian Civil Rights Watch, and Mass Resistance. One such organization, a nonprofit founded in Colorado Springs in 1991, was Colorado for Family Values (CFV). According to its mission statement, its role is to "pro-actively lead and assist those opposing the militant homosexual attack on traditional family values" [26].

CFV sponsored an initiative to amend the state constitution and gathered enough signatures to include it on the November 1992 ballot. The initiative, known as Amendment 2, read:

Neither the State of Colorado, through any of its branches or departments, nor any of its agencies, political subdivisions, municipalities or school districts, shall enact, adopt or enforce any statute, regulation, ordinance or policy whereby homosexual, lesbian or bisexual orientation, conduct, practices or relationships shall constitute or otherwise be the basis of or entitle any person or class of persons to have or claim any minority status, quota preferences, protected status or claim of discrimination. This Section of the Constitution shall be in all respects self-executing.

The sweeping language of this initiative was extraordinary. As US Supreme Court Justice Sandra Day O'Connor later observed [25] during oral arguments about its constitutionality, "The literal language would seem to indicate, for example, a public library could refuse to allow books to be borrowed by homosexuals and there would be no relief from that." The proponents of this measure often summarized their argument as No Special Rights, claiming that they were only interested in prohibiting "special rights" for sexual minorities [13, 26]. Although surveys showed that the majority of Colorado residents opposed discrimination based on sexual orientation, the "no special rights" argument convinced enough people, and Amendment 2 passed by $53 \%$ to $47 \%$ [8].

\section{Letter Writing}

When David Pengelley, a mathematician then at New Mexico State University, learned of the passage of Amendment 2, he immediately connected this with the Joint Mathematics Meetings scheduled for Denver in January 1995. Although these meetings are planned years ahead, he decided to write to the members of the AMS Council and the MAA Board of Governors, urging them to move the meeting out of Colorado. His letter [21] reads in part:

- It would be both unfair and insulting to the many homosexual members of the AMS and MAA to be asked to attend an annual meeting in an openly hostile and potentially more dangerous place.

- It is important that this dangerous and intolerant action in Colorado not become a national trend, and the AMS and MAA, along with many other organizations, can help ensure this by not being accomplices. Already many organizations like ours are making such decisions by cancelling convention bookings. One might hope that this will also influence the people of Colorado to change their actions, if not their prejudices.

- Finally, many heterosexual members, like myself, would also be unwilling to be accomplices to this trend by attending an annual meeting in Colorado, and thus attendance and program quality in Denver would suffer, and many members would be alienated.

At the same time, James Humphreys at the University of Massachusetts, Amherst, had similar misgivings. Although he felt that Denver was more progressive than most parts of the state, he thought that the symbolism of having thousands of mathematicians spend lots of money in Colorado was important to avoid. Unaware of Pengelley's efforts, he also decided to write individual letters to all AMS officers and members of the AMS Council urging them to consider moving the JMM. This was a time when a newfangled method of communication called electronic

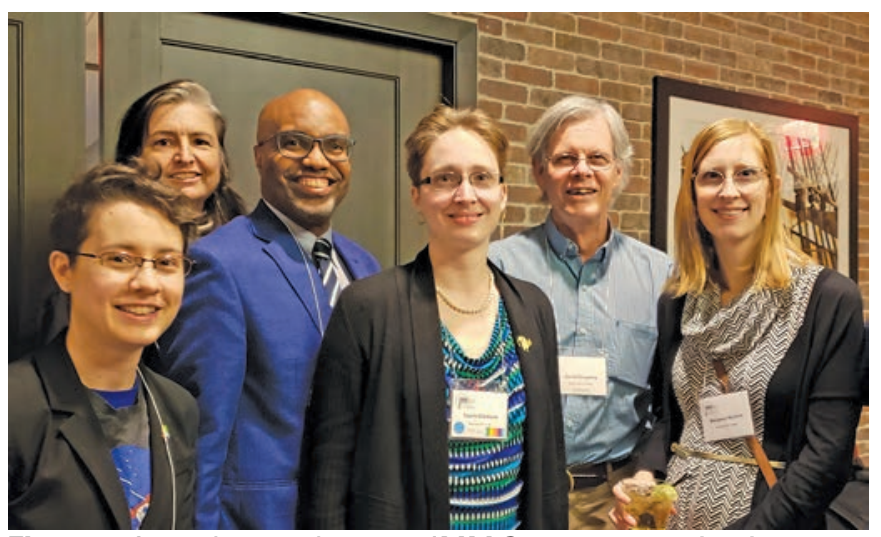

Figure 1. Attendees at the $2019 \mathrm{JMM}$ Spectra reception in Baltimore, including David Pengelley (second from right), his first time attending a Spectra reception. 
mail was just starting to become widespread. However, it was quite difficult to find email addresses for a group of people as large as the AMS Council and MAA Board of Governors. So both Pengelley and Humphreys put their letters into individually addressed and stamped envelopes and mailed them off (more than a hundred altogether) in the first week of December 1992. They understood that the governing boards of the professional societies would be meeting shortly at the January 1993 JMM in San Antonio, and wanted this issue on their radar. Neither was optimistic his letter would result in concrete action. They were wrong.

\section{Societies React}

This was not the first time that mathematicians had urged the professional societies to become more inclusive. There is, for example, a rich history of activism on the part of African-American mathematicians and allies against segregation [14].

The letters from Pengelley and Humphreys created a flurry of responses and activity. Time was short. The holidays were fast approaching, and the JMM was convening in early January. Nevertheless, a series of email exchanges between Pengelley and some of those contacted showed there was strong support for the idea of moving the JMM away from Colorado, and that this would be put on the agenda at the governance meetings of both the AMS and MAA.

The schedule of governance meetings was crucial. First up was the MAA Executive and Finance Committee, then the full MAA Board of Governors, and finally the AMS Council. Deborah Tepper Haimo, then president of the MAA, made sure this was on the agenda of the first meeting. She thought a move would have strong support and, indeed, said that no one she had talked with thought there would be any question about moving the JMM meeting site, despite added costs and difficulties with the relocation. She was right. The MAA Executive and Finance Committee recommended the move to their Board of Governors, which was meeting the next day. After that, the AMS Council convened and also was in general agreement to move the meeting.

At an unprecedented joint meeting of the governing boards arranged by AMS President Michael Artin and MAA President Haimo, there was strong sentiment for moving the 1995 JMM out of Colorado [9]. However some participants were opposed, citing both the unknown financial consequences and whether professional organizations should take political stands on this issue. After an hour and a half of discussion, parallel motions were prepared and voted on by the AMS Council and MAA Board. The AMS resolution [1] read:

The Council of the AMS believes that the actions taken by the majority of those voting in Colorado in November 1992 with respect to dis- crimination against homosexuals were wrong. The Council of the AMS recommends that the Joint Meetings not take place in Colorado while language similar to that in Amendment 2 of the November 1992 General Election passed by the voters of Colorado remains in the Colorado constitution. One of the reasons for this resolution is that the AMS has the duty to protect all participants at their meetings from possible discrimination.

The Council of the AMS delegates the responsibility for final action to the AMS Board of Trustees and the MAA Executive and Finance Committee, who will instruct the Joint Meetings Committee to make every effort to find a site for the January 1995 meeting in a state other than Colorado.

The Council of the AMS requests that the sentiments of this resolution be communicated to the Governor of Colorado.

The AMS Council passed their version unanimously, and the MAA Board approved theirs by a vote of thirty-six in favor to seven against with two abstentions. The executive bodies reconvened and the votes were announced. According to Devlin [9], President Haimo's update at an MAA meeting two days later received a "large and spontaneous round of applause."

Meanwhile the AMS Meetings staff had been working with their MAA counterparts to find an alternative venue that could be part of these discussions. They recommended San Francisco-always a popular choice, and it had clear symbolic value as well. Four days after these resolutions passed, the Joint Meetings Committee met and agreed to move the meeting from Denver to San Francisco. They also resolved to obtain convention cancellation insurance for all future JMM meetings, and to alert the mayors, chambers of commerce, and convention bureaus in the future sites of JMMs about their intentions and history regarding anti-civil rights legislation. All future hotel contracts for the JMM now include a "Change of Legislation" clause.

A Denver Negotiating Team handled the terms of the cancellation in Denver. Two Denver hotels made claims on the AMS and MAA for damages. All parties settled for a total of $\$ 35,000$ in damages, half paid by AMS and half paid by MAA [22]. Although not certain, it seems likely that increased attendance due to the change in location from Denver to San Francisco made up most, if not all, of this amount.

MAA FOCUS received six letters opposing the move. FOCUS Editor Keith Devlin decided to publish three [20], explaining in a preceding editorial that although he thought that these represented a minority view, they deserved to be heard. 


\section{HISTORY}

\section{Colorado Boycott}

The passage of Amendment 2 was the first major success of a series of similar anti-LGBT rights activities at the time in many other states, including Arizona, California, Florida, Georgia, Idaho, Iowa, Maine, Michigan, Minnesota, Missouri, Montana, Ohio, Oregon, and Washington [12]. The strategy and tactics of Colorado for Family Values, especially their No Special Rights slogan, provided a

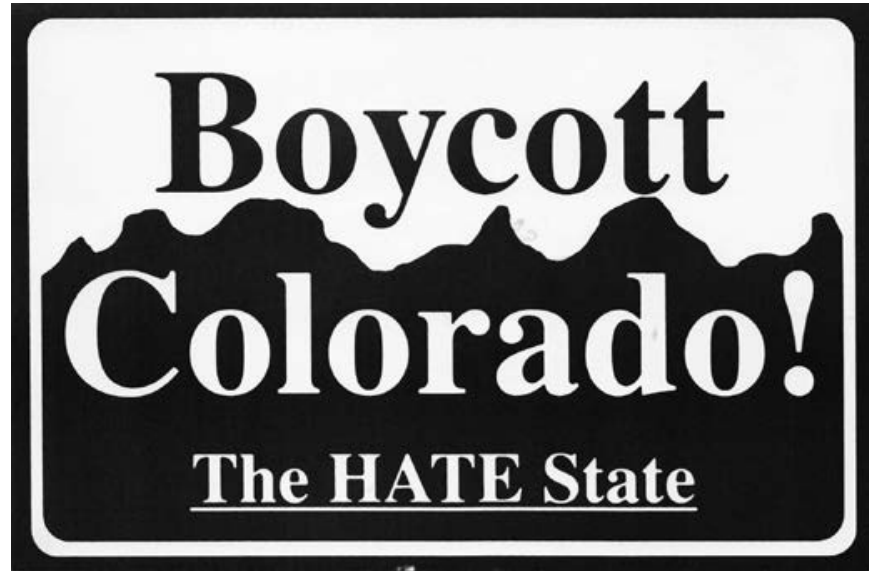

Figure 2. Boycott Colorado was formed as a way to fight back against attacks on anti-discrimination laws.

In December 1994 the Colorado Supreme Court struck down Amendment 2 as unconstitutional [7]. The activities of Boycott Colorado were suspended, as they awaited further legal developments [26].

\section{Initial LGBT Reception}

In the fall months of 1994 , Don Goldberg of Occidental College in Los Angeles contacted others interested in organizing a social event at the January 1995 meetings, rescheduled for San Frantemplate for similar groups nationwide.

Alarmed by these developments, a number of individuals and groups considered ways to fight back against this wave of attacks on anti-discrimination laws. The idea of an economic boycott of Colorado gained steam, and by early 1993 the group Boycott Colorado formed as a clearinghouse to publicize and organize these efforts. The boycott sought to deter similar anti-LGBT efforts elsewhere, even encouraging business and political leaders to actively oppose copycat initiatives $[2,26]$. The boycott idea proved controversial-boycotts are blunt instruments that can harm those sympathetic to its goals-but it also proved effective.

Three months into the boycott, about three dozen conventions scheduled for Colorado had been cancelled, including the 1995 JMM. By June 1993, Boycott Colorado had enlisted more than one hundred organizations and individuals to endorse this effort, including municipalities such as Chicago, Los Angeles, and New York, resulting in cancelled contracts for Colorado businesses [4]. NBC even changed the locale of its new television series Frasier from Denver to Seattle [26].

Estimates of the economic impact on Colorado from the boycott range from $\$ 40$ million to $\$ 120$ million, but, even assuming the highest estimate, this represented only $2 \%$ of the state's tourism budget [26].

More importantly, the boycott took a serious toll on Colorado's reputation. From innumerable newspaper articles and other publicity, Colorado acquired the epithet "The Hate State." Within the state, many companies and individuals did what they could to counteract this. They adopted and publicized nondiscrimination policies covering sexual orientation, and some required any vendors they did business with to adopt similar policies. Among these efforts was the Colorado Alliance for Restoring Equality, a Denver-based group of businesses and community groups devoted to overturning Amendment 2 [26].

cisco. The organizers shared the belief that, in the wake of the decision by the AMS and MAA governing bodies to relocate the 1995 meetings, this was an appropriate time for mathematicians belonging to sexual minorities to establish a visible presence within the profession. The steering committee that organized the event consisted of Robert Bryant (Duke University), Don Goldberg (Occidental College), Concha Gomez (University of California, Berkeley), Steven Hillion (University of California, Berkeley), James Humphreys (University of Massachusetts at Amherst), Nadine Kowalsky (Institute for Advanced Study), Janet Ray (Seattle Central Community College), and Sandra Rhoades (now Gokey) (Smith College) [10].

The AMS staff was helpful in arranging for an announcement of an LGBT reception to be listed with other informal events in the Meetings Daily Newsletter. It was held at the Iron Horse, a nearby restaurant and bar, with nearly one hundred attendees. As at most social occasions at the meetings, the discussion ranged over research problems, teaching methods, mutual friends and colleagues, jobhunt networking, the forging of new friendships, and the renewal of old ones. One man, in his sixties, remarked that at meetings years ago he thought he was the only gay mathematician in attendance and was gratified by the size of the gathering. One graduate student was pleasantly surprised to see the author of a favorite book at the reception. Frank Farris [11] has recently written a personal account describing the significance of this event to him.

Many people expressed the desire to have such a gathering at every national meeting. It also became apparent that discussion of sexual orientation issues related to the mathematics profession should be continued beyond the debate over the location of a single meeting. Two email lists were set up to continue communications. These receptions became annual events at the JMM, initially organized by George Bradley of Duquesne University, who scheduled them at the conference hotel, supported them with his own 
funds, and gathered donations until 2009, when others agreed to take over these duties.

\section{Supreme Court Decision}

Amendment 2 was challenged in the courts nine days after passage by a group consisting of individuals and municipalities. The lead plaintiff was Richard Evans, a gay man who worked for the mayor of Denver. Jean Dubofsky, well known in Colorado legal circles as the youngest person and first woman appointed to the Colorado Supreme Court where she served until 1987, led the legal team. A permanent injunction prevented the measure from taking effect. On October 11, 1994, almost two years after its passage, the Colorado Supreme Court ruled 2-1 that Amendment 2 was unconstitutional [7].

Supporters of the amendment then appealed to the US Supreme Court, which accepted the case in February 1995. Although the Colorado Governor Roy Romer had opposed the initiative, he was obligated to defend it in court. And so the case became known as Romer $v$. Evans $[23,24]$.

Dubofsky again led the team challenging the amendment, this time in federal court. The stakes were enormous, especially since a definitive ruling would have serious impacts on similar anti-LGBT initiatives that were at various stages of legal challenge around the country. As the team prepared, they were helped by John Roberts, then an appellate attorney and now Chief Justice of the US Supreme Court, as part of his pro bono work. Dubofsky later said that Roberts was "terrifically helpful in meeting with me and spending some time on the issue. He seemed to be very fair-minded and very astute" [28].

Oral arguments were heard on October 10, 1995. For a vivid account of the chaotic scene outside the Supreme Court building (with long lines of people trying to secure one of the few seats to witness the historic case) and the tense, dramatic legal exchanges that occurred inside, see Casey $[5,6]$.

The audio recording of the hour-long hearing (together with the transcript) is available at [25] and is fascinating to listen to. Justice Ruth Bader Ginsberg asked the lead lawyer for the state, "I would like to know whether in all of US history there has been any legislation like this that earmarks a group and says, you will not be able to appeal to your State legislature to improve your status." Justice Antonin Scalia hammered away on special-rights arguments. He also asked Dubofsky point-blank, "Are you asking us to overrule Bowers v. Hardwick?," referring to the earlier decision that justices were loath to revisit. She deftly showed the justices how they could find Amendment 2 unconstitutional without overturning Bowers.

On May 10, 1996, the US Supreme Court announced its decision in Romer v. Evans [23]. By a 6-3 majority, it ruled Amendment 2 unconstitutional, although for different reasons than those given by the Colorado Supreme Court.

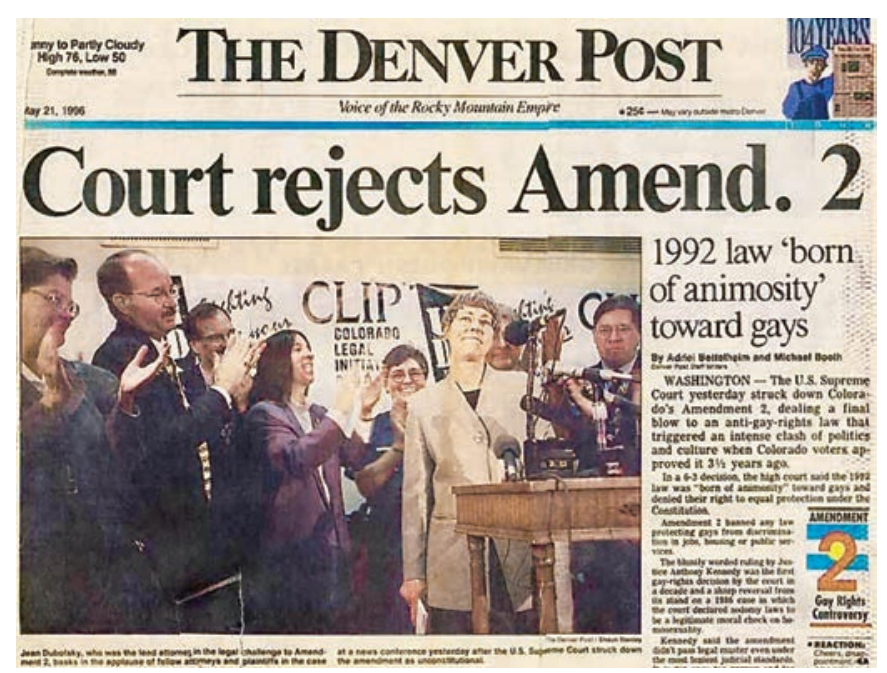

Figure 3. Headline announcing the US Supreme Court decision striking down Amendment 2.

Justice Kennedy, writing for the majority (with Justices Stevens, O'Connor, Souter, Ginsburg, and Breyer concurring), said that the law "is at once too narrow and too broad. It identifies persons by a single trait and then denies them protection across the board. The resulting disqualification of a class of persons from the right to seek specific protection from the law is unprecedented in our jurisprudence" and "Its sheer breadth is so discontinuous with the reasons offered for it that the amendment seems inexplicable by anything but animus toward the class that it affects; it lacks a rational relationship to legitimate state interests." He also addressed the No Special Rights argument head-on, saying, "We find nothing special in the protections Amendment 2 withholds. These are protections taken for granted by most people either because they already have them or do not need them" [23].

A dissenting opinion authored by Justice Scalia (joined by Justice Thomas and Chief Justice Rehnquist) began, "The Court has mistaken a Kulturkampf for a fit of spite." It continued, "In holding that homosexuality cannot be singled out for disfavorable treatment, the Court contradicts a decision, unchallenged here, pronounced only 10 years ago, see Bowers $v$. Hardwick ... , and places the prestige of this institution behind the proposition that opposition to homosexuality is as reprehensible as racial or religious bias." It also said that "Amendment 2 is designed to prevent piecemeal deterioration of the sexual morality favored by a majority of Coloradans, and is not only an appropriate means to that legitimate end, but a means that Americans have employed before" [23].

The Romer decision to strike down Amendment 2 marked a turning point in the legal battles to secure the civil rights of LGBT people. At least temporarily, it also turned back the tide of similar efforts to challenge and re- 


\section{HISTORY}

strict LGBT civil rights, although later these have resurfaced using subtler tactics.

The reverberations from this decision continue to be felt. In its 2003 decision Lawrence $v$. Texas, the US Supreme Court ruled 6-3 that Bowers $v$. Hardwick had been wrongly decided, effectively decriminalizing same-sex relationships nationwide by invalidating the sodomy laws that still remained on the books in sixteen states at the time [15]. In the 2015 decision Obergefell $v$. Hodges, the Court ruled 5-4 that the fundamental right to marry is guaranteed to samesex couples by both the Due Process Clause and the Equal Protection Clause of the Constitution [18, 19]. As in Romer and Lawrence, the majority opinion here was authored by Justice Kennedy, while Chief Justice Roberts dissented.

On November 6, 2018, the citizens of Colorado elected Jared Polis as governor, the first time in US history that an openly gay person was elected a state governor [27].

\section{Creation of Spectra}

For many years George Bradley continued to organize and support receptions for LGBT mathematicians at both the Joint Meetings in the winter and MAA's MathFests in the summer. In 2007 Bradley organized an LGBT Math Caucus within the National Organization of Gay and Lesbian Scientists and Technical Professionals (NOGLSTP [17]), a nonprofit organization led by Rochelle Diamond and Barbara Belmont to support LGBT STEM professionals. Since then, NOGLSTP has provided financial and administrative support for the annual JMM reception, as well as serving as the place individuals can send tax-deductible donations for the reception.

At an informal meeting of LGBT mathematicians at the 2010 JMM in San Francisco, faced with Bradley's understandable desire for others to take over this role, several participants pledged some on-going financial support. Christopher Goff (University of the Pacific) stepped up to be the primary organizer of the annual JMM receptions, while Mark MacLean (Seattle University) continued as organizer of the informal off-site receptions. The sense also grew over the next few years that a more formal organization could not only sustain this activity but also provide other valuable ways to support LGBT mathematicians.

David Crombecque had already taken over for Bradley in the LGBT Math Caucus. A small group, serving as a steering committee, started brainstorming ideas of what other things could be done to support mathematicians regardless of sexual orientation, gender expression, or gender identity. Searching for a good name for the nascent organization, Robert Bryant (Duke University) and Mike Hill (University of California, Los Angeles) suggested the colorful term "Spectra," with both mathematical and cultural associations. The Spectra website at www. 1gbtmath . org has information about the people involved and sponsored events, as well as a way to subscribe to the Spectra email list. It also has links to resources, including primary source materials used to prepare this article.

The first official Spectra event was a panel discussion at the 2015 JMM in San Antonio called "Out in Mathematics: LGBTQ Mathematicians in the Workplace." David Crombecque (University of Southern California) moderated a lively and well-attended discussion featuring Andrew Bernoff (Harvey Mudd College), Julie Blackwood (Williams College), Kristina Garrett (St. Olaf College), Mike Hill (UCLA), and Marie Vitulli (University of Oregon).

A similar panel discussion took place at the 2018 JMM

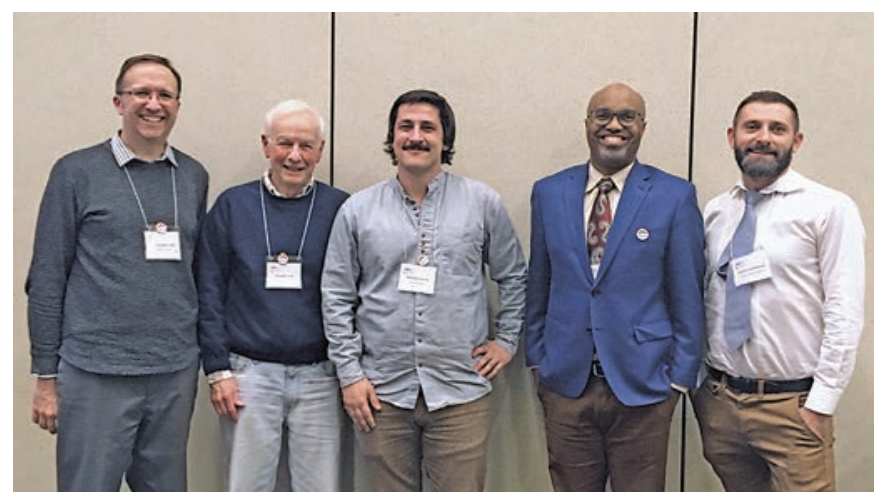

Figure 4. Discussion leaders at the SpectraTown Hall meeting at the 2019 JMM, I to r: Christopher Goff, Douglas Lind, Alexander Hoover, Ron Buckmire, and David Crombecque.

in San Diego, moderated by Lily Khadjavi (Loyola Marymount University), and with panelists Shelly Bouchat (Indiana University of Pennsylvania), Juliette Bruce (University of Wisconsin-Madison), Ron Buckmire (National Science Foundation), Frank Farris (Santa Clara University), and Emily Riehl (Johns Hopkins University). Participants shared their experiences and perspectives. Gathered in a large and supportive audience, attendees raised a wide range of concerns: Should a graduate student on the job market avoid even applying for work in states where adoption would be a legal struggle for him and his husband? How does a graduate student or faculty member get an institution and colleagues to respectfully recognize their gender identity, from day-to-day interactions to official documents? How does one navigate working with an advisor who may not understand or be mindful of these issues? Reactions and responses illustrated that the environment still varies tremendously from institution to institution, as does the legal landscape from state to state. For example, a majority of states in the US do not have prohibitions against employment discrimination based on sexual orientation and gender identity [30].

Spectra held a Town Hall meeting at the 2019 JMM in Baltimore, where participants divided into small groups focused on topics that included teaching and job search issues, together with how Spectra can help raise the visibility of the LGBT community within their departments. 


\section{Looking Ahead}

With generous contributions from several donors, Spectra has been able to continue the tradition of annual JMM receptions, organized in recent years by Christopher Goff (University of the Pacific) and currently Douglas Lind (University of Washington). Everyone is warmly welcome to attend these events and to contribute any ideas or suggestions they may have for future Spectra activities, as well as to donate funds to support these events.

Throughout, the leadership and staff at our professional societies have been extremely receptive and supportive. Both societies have strong anti-discrimination policies. In 2015 Christopher Goff was appointed the inaugural At-Large Member for Inclusion in the MAA's Council on the Profession, where he still serves. In 2016 Helen G. Grundman was named the inaugural Director of Education and Diversity at the AMS, and she has given Spectra generous encouragement and support. As a recent example, at Spectra's urging the Joint Mathematics Meetings will now provide some well-labeled "All Gender" bathrooms. We are very grateful to all those individuals who have helped Spectra over the years.

The 2020 Joint Math Meetings will be held in Denver, the first time the JMM will be in Colorado since the events recounted here. We encourage participants to celebrate the progress already made and the role our professional organizations play in creating an inclusive environment for all attendees.

The visible presence of LGBT, nonbinary, and gender nonconforming people among mathematicians is an im-

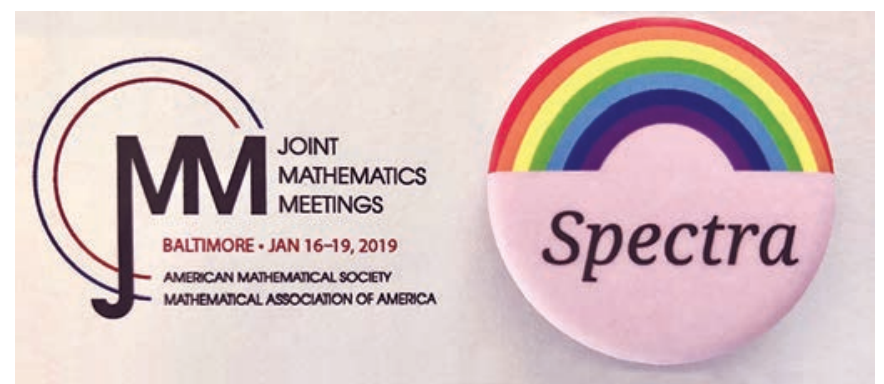

Figure 5. Pins that Spectra supporters could wear during the 2019 JMM to increase their visibility.

portant sign of the diversity of the mathematics community. As educators, all mathematicians should be aware of the challenges facing our students and colleagues. Despite advances in recent years, the societal and professional environment is not as welcoming as it could be to those who are underrepresented mathematicians. Often they feel like they cannot participate fully in the mathematics community while simultaneously expressing all aspects of their identity. The ability to do so should be a goal of all our professional societies.
There will be many challenges ahead. But we hope that the publication of this story serves as an inspirational example of how individuals, working together with their professional societies, can advance the inclusiveness of the mathematical community in important, concrete, and visible ways.

ACKNOWLEDGMENTS. In preparing this article, the authors would like to gratefully acknowledge the contributions of George Bradley, Susan Berry Casey, David Crombecque, Keith Devlin, Christopher Goff, Concha Gomez, Frank Farris, Don Goldberg, James Humphreys, William "Bus" Jaco, Linda Keen, David Pengelley, Penny Pina, and Janet Ray.

\section{References}

[1] Council Minutes of the American Mathematical Society, Jan. 12, 1993.

[2] Anderson S. Why Colorado is Being Boycotted? Denver Post, Jan. 9, 1993.

[3] Bowers v. Hardwick. 478 US 186. United States Supreme Court. 1986. Available at https://caselaw. findlaw.com /us-supreme-court/478/186.htm7.

[4] Boycott Colorado website, http://www. qrd.org/qrd/www /FTR/boycott.htm1.

[5] Casey SB. Appealing For Justice: One Lawyer, Four Decades and the Landmark Gay Rights Case: Romer v. Evans, Gilpin Park Press, Denver, 2016.

[6] Casey SB. Nine Justices and One Colorado Lawyer, Colorado Heritage Magazine, November/December 2016.

[7] Colorado Supreme Court ruling in Evans v Romer, https:// 7 aw.justia.com/cases/colorado/supreme-court/1994 /94sa48-0.htm7.

[8] Colorado's Amendment 2 vote, https://ba11otpedia .org/Colorado_No_Protected_Status_for_Sexual -Orientation_Amendment,_Initiative_2_(1992).

[9] Devlin, K. MAA and AMS Vote to Move 1995 January Meetings from Colorado, MAA FOCUS 13 (1993), 4-5.

[10] E-mail Discussion List on Sexual Orientation Issues in the Mathematical Community, Notices of the AMS, April, $1995,471$.

[11] Farris F. LGBT Math - Out of the Closet, MAA FOCUS February/March 2019, 26-28.

[12] Gascoyne, S. Colorado Anti-gay-rights Amendment Takes Toll in State, Christian Science Monitor, March 18, 1993. Available at https://www. csmonitor.com/1993 /0318/18032.htm7.

[13] Hirshman L. Victory: The Triumphant Gay Revolution, 1st ed. HarperCollins, New York, 2012.

[14] Kenshaft P. Black Men and Women in Mathematical Research, Journal of Black Studies, 18, No. 2 (Dec., 1987), 170190, https://doi .org/10.1177/002193478701800204.

[15] Lawrence v. Texas, https://en.wikipedia.org/wiki /Lawrence_v._Texas.

[16] Miller N. Out of the Past: Gay and Lesbian History from 1869 to the Present, 1st ed. Vintage Books, New York, 1995.

[17] National Organization of Gay and Lesbian Scientists and Technical Professionals, https://wwww.nog7stp.org.

[18] Obergefell v. Hodges, https://en.wikipedia.org /wiki/Obergefe11_v._Hodges. 


\section{HISTORY}

[19] Obergefell v. Hodges. 135 S. Ct. 2584. United States Supreme Court. 2015. Available online: https://www . supremecourt.gov/opinions/14pdf/14-556_3204.pdf. (accessed on February 1, 2019).

[20] Opinion Column, MAA FOCUS 13 No. 5 (1993), 10-11.

[21] Pengelley D. Letter to AMS Council and MAA Board of Governors, November, 1992.

[22] Pina P. Electronic communication to Douglas Lind, October 4, 2016.

[23] Romer v. Evans. 517 US 620. United States Supreme Court. 1996. Available online: https://caselaw. findlaw .com/us-supreme-court/517/620.htm1 (accessed on December 15, 2018).

[24] Romer v. Evans, https://en.wikipedia.org/wiki /Romer_v._Evans.

[25] Oral Arguments in Romerv. Evans, United States Supreme Court, October 10, 1995. Audio available at https:// www.oyez.org/cases/1995/94-1039.

[26] Sen S. Marketing and Minority Civil Rights: The Case of Amendment 2 and the Colorado boycott, Journal of Public Policy \& Marketing 15 No. 2, 311-318.

[27] Schneier M. Colorado's Got a Gay Governor. Who Cares? New York Times, Jan. 9, 2019. Available at https://www. nytimes.com/2019/01/09/style/jared -polis-gay-governor.htm1.

[28] Serrano RA. Roberts Donated Help to Gay Rights Cause, Los Angeles Times, Aug. 4, 2005. Available at http:// articles.1atimes.com/2005/aug/04/nation/na -roberts4

[29] Shilts R. And The Band Played On: Politics, People and the AIDS Epidemic, 1st ed. St. Martin's Press, New York, 1987.

[30] State Maps of Laws \& Policies. Human Rights Campaign, https://www.hrc.org/state-maps/employment.

[31] Update: Mortality Attributable to HIV Infection Among Persons Aged 25-44 Years - United States, 1991 and 1992. Morbidity and Mortality Weekly Report, November 19, 1993. Available at https://www.cdc.gov/mmwr/preview /mmwrhtm1/00022174.htm.

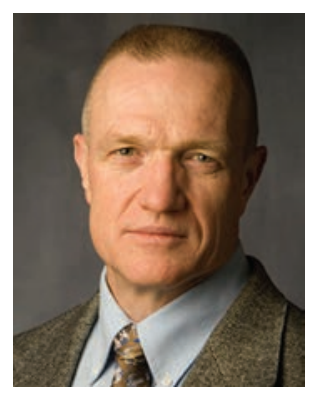

Robert Bryant

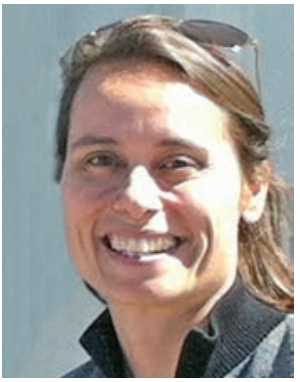

Lily Khadjavi

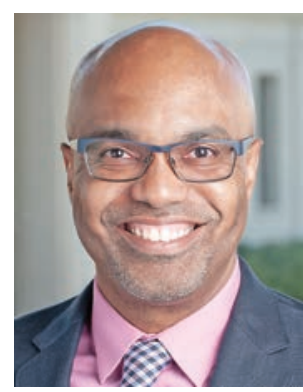

Ron Buckmire

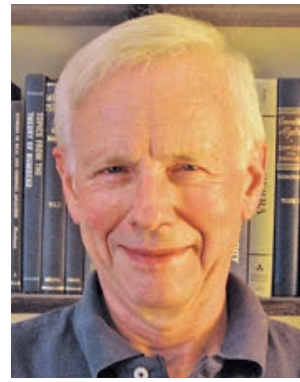

Douglas Lind

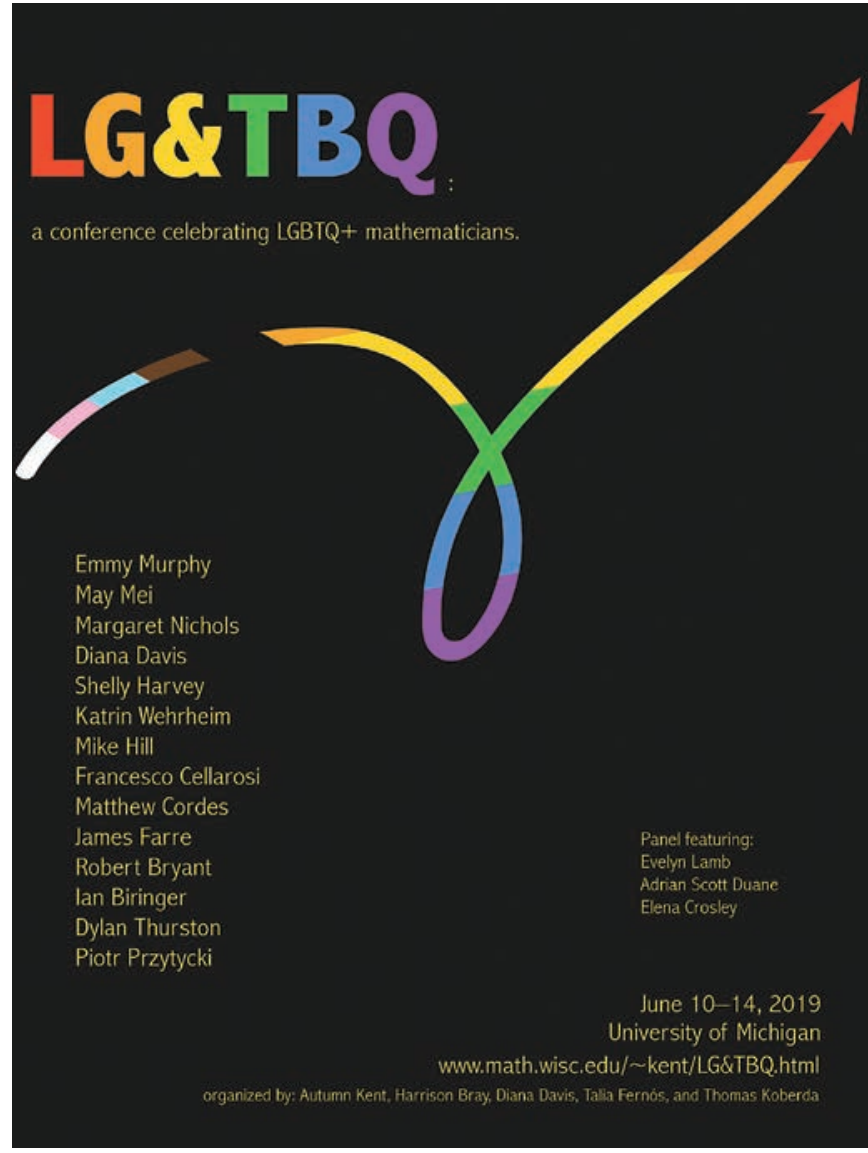

To promote community among LGBTQ+ mathematicians, who are often scattered and isolated, Harrison Bray and Autumn Kent established LG\&TBQ, a conference at the University of Michigan this summer to foster collaboration and mentoring in geometry, topology, and dynamical systems. They hope this will spur similar efforts in other scientific areas.

\section{Credits}

Figure 1 is by David Crombecque.

Figure 2 is from the personal papers of Jean Dubofsky.

Figure 3 is courtesy of the Denver Post.

Figure 4 is by Anya Bartelmann.

Figure 5 is by Douglas Lind.

Photo of Robert Bryant is by Duke Photographic Services.

Image of LG\&BTQ Conference poster is courtesy of Autumn Kent.

All other author photos are courtesy of the authors themselves. 